\title{
Keberlanjutan Program One Village One Product melalui Manajemen Koperasi Tani Mertanadi di Desa Pelaga, Kecamatan Petang, Kabupaten Badung
}

\author{
I GEDE VIBHUTI KUMARANANDA, NYOMAN SUTJIPTA, \\ I G A A LIES ANGGRENI
}

Program Studi Agribisnis, Fakultas Pertanian, Universitas Udayana

Jl. PB. Sudirman Denpasar 80323

Email: vibhuti.kn10@gmail.com

nsutjiptacipta@yahoo.com

\begin{abstract}
Sustainability of One Village One Product (OVOP) Program Through Mertanadi Farmers Cooperative Management (In the Case of Pelaga Village, Petang SubDistrict, Badung Regency).
\end{abstract}

Indonesia's development through village development is one of the government's focus on alleviating poverty in Indonesia. Overcoming the problem of poverty, the government has launched several programs, one of which is to build Indonesia from the village. One of the programs to build Indonesia from the village is the One Village One Product (OVOP) program. It is a regional potential development approach in one region to produce one global class product by utilizing local resources. One of the successful villages in running the OVOP program is Pelaga Village located in Petang Sub-District, Badung Regency. This study aims to determine the sustainability of the OVOP program through the management of Mertanadi Farmers' Cooperative and to investigate the constraints that occur in the management of Mertanadi Farmers' Cooperative. Data collection was done by distributing questionnaires to determine the members' assessment on the sustainability of the OVOP program and using the interview guidelines to find out the management of Mertanadi Farmers' Cooperative. Then the data was analyzed by qualitative descriptive analysis method, which was presented in quantitative analysis. The results of the research showed that the sustainability of the OVOP program through the management of Mertanadi Farmers Cooperative in Pelaga Village, Petang Sub-district, Badung Regency obtained a score of 4.00 with a percentage of $80 \%$ that it can be categorized as in the successful category. Technical, social, and economic constraints need to be anticipated to maintain the sustainability of the OVOP program.

Keywords: OVOP Program, asparagus, management, cooperative 


\section{Pendahuluan}

\section{$1.1 \quad$ Latar Belakang}

Salah satu program yang memiliki tujuan membangun Indonesia dari desa adalah program One Village One Product (OVOP). One Village One Product (OVOP) adalah pendekatan pengembangan potensi daerah di satu wilayah untuk menghasilkan satu produk kelas global yang unik khas daerah dengan memanfatkan sumber daya lokal. Satu desa sebagaimana dimaksud nantinya dapat diperluas menjadi kecamatan, kabupaten, maupun kesatuan wilayah lainnya sesuai dengan potensi dan skala usaha secara ekonomis. Pada tahun 2010 terdapat kerjasama antara kementerian pertanian dan kementerian koperasi untuk mengembangkan program One Village One Product (OVOP) di Desa Pelaga, Kecamatan Petang, Kabupaten Badung. Desa Pelaga termasuk salah satu kawasan yang berhasil dalam penerapan program One Village One Product (OVOP) dengan menggunggulkan komoditi asparagus. Manajemen program OVOP di Desa Pelaga menggunakan lembaga koperasi, yang bernama Koperasi Tani Mertanadi. Manajemen dikelola oleh koperasi dalam artian bibit asparagus disediakan oleh koperasi, dimana pemasaran hasil produk melalui koperasi. Pengembangan program OVOP di Desa Pelaga, Kecamatan Petang, Kabupaten Badung pada awalnya bekerjasama dengan salah satu lembaga swadaya masyarakat (LSM) dari Taiwan, yaitu Taiwan Technical Mission (TTM). Pendampingan dari Taiwan Technical Mission (TTM) di lakukan selama 5 s.d 6 tahun lamanya hingga petani di Desa Pelaga mampu mandiri dalam menjalankan program OVOP.

Program OVOP di Desa Pelaga yang telah berlangsung selama delapan tahun ini merupakan suatu gerakan ekonomi bagi masyarakat Desa Pelaga dan mempunyai prospek yang cukup bagus kedepannya. Keberhasilan program One Village One Product (OVOP) di Desa Pelaga ini tidak lepas dari sistem manajemen Koperasi Tani Mertanadi yang telah terlaksana dengan baik. Peneliti ingin mengetahui bagaimana sistem manajemen Koperasi Tani Mertanadi dalam keberlanjutan program OVOP melalui manajemen Koperasi Tani Mertanadi di Desa Pelaga yang sudah terlaksana, dan kendala yang dialami dalam pelaksanaan program sehingga dapat dijadikan referensi atau rekomendasi untuk desa atau kabupaten yang ingin melaksanakan program One Village One Product (OVOP).

\subsection{Rumusan Masalah}

Berdasarkan latar belakang di atas, adapun rumusan masalah yang penulis dapatkan, yaitu sebagai berikut.

1. Bagaimanakah keberlanjutan program One Village One Product (OVOP) melalui manajemen Koperasi Tani Mertanadi di Desa Pelaga, Kecamatan Petang, Kabupaten Badung.

2. Kendala yang dialami pada saat berjalannya program One Village One Product (OVOP) di Desa Pelaga, Kecamatan Petang, Kabupaten Badung. 


\subsection{Tujuan Penelitian}

Berdasarkan rumusan masalah di atas, adapun tujuan penelitian ini sebagai berikut.

1. Untuk mengetahui keberlanjutan program One Village One Product (OVOP) melalui manajemen Koperasi Tani Mertanadi di Desa Pelaga, Kecamatan Petang, Kabupaten Badung.

2. Untuk mengetahui kendala yang dialami pada saat berjalannya program One Village One Product (OVOP) di Desa Pelaga, Kecamatan Petang, Kabupaten Badung.

\section{Metode Penelitian}

\subsection{Lokasi dan Waktu Penelitian}

Penelitian ini dilaksanakan di Desa Pelaga, Kecamatan Petang, Kabupaten Badung. Penelitian ini dilaksanakan selama lima bulan yakni dari bulan September 2017 sampai Februari 2018.

\subsection{Data}

Sumber data yang diperlukan dalam penelitian ini adalah primer dan data sekunder. Data primer adalah data yang didapatkan langsung dari lapangan. Data sekunder yakni data yang didapatkan dari sumber lain seperti laporan hasil usaha di Koperasi Tani Mertanadi, penunjang tinjauan pustaka berdasarkan referensi dari bukubuku, literatur atau pedoman menjalankan program OVOP, media massa online, dan sumber lainnya.

\subsection{Responden Penelitian dan Informan Kunci}

Responden penelitian ini adalah petani di Desa Pelaga yang menjadi anggota dari Koperasi Tani Mertanadi dan aktif berproduksi, yaitu sebanyak 76 orang ditambah dengan empat orang informan kunci. Informan kunci tersebut yakni I Wayan Supariyasa sebagai ketua Koperasi Tani Mertanadi, I Dewa Made Medal sebagai sekretaris Koperasi Tani Mertanadi, I Nyoman Sudarta sebagai bendahara Koperasi Tani Mertanadi, dan Ida Ayu Yanti Agustini, SH, MM dari Dinas Koperasi, UKM Perindustrian dan Perdagangan Kabupaten Badung.

\subsection{Pengumpulan Data}

Metode pengumpulan data merupakan teknik pengumpulan data untuk memperoleh data dan keterangan-keterangan yang mendukung penelitian (Sugiyono, 2014). Metode pengumpulan data dilakukan dengan cara observasi, wawancara dan dokumentasi. Observasi digunakan untuk mengumpulkan data dengan cara melakukan pengamatan aktivitas kegiatan Koperasi Tani Mertanadi. Wawancara digunakan untuk mengumpulkan data dengan menggunakan pedoman wawancara dan kuesioner. 
Pedoman wawancara untuk mendapatkan data mengenai Koperasi Tani Mertanadi secara lebih mendalam dan kuesioner digunakan untuk menilai keberlanjutan program One Village One Product (OVOP) melalui manajemen Koperasi Tani Mertanadi di Desa Pelaga, Kecamatan Petang, Kabupaten Badung. Dokumentasi digunakan sebagai pelengkap dari penggunaan metode observasi dan wawancara untuk menambah kredibilitas dalam penelitian kualitatif.

\subsection{Metode Analisis Data}

Analisis data dalam penelitian ini menggunakan metode analisis deskriptif. Hasil analisis dekriptif dalam penelitian ini didapatkan melalui pengumpulan data melalui metode kuantitatif, yaitu berupa olahan data dari kuesioner yang disebarkan yang kemudian dideskripsikan dan hasil dari pengumpulan data kualitatif yang didapatkan melalui wawancara. Tahap pertama dalam menganalisis data dengan cara menyeleksi data sesuai dengan fokus permasalahan, tahap kedua, yaitu mendeskripsikan data. Analisis data menggunakan metode skoring dalam mengukur variabel penelitian. Skor 1 merupakan skor minimum dan skor 5 merupakan skor maksimum. Skor yang telah diperoleh selanjutnya akan didistribusikan dalam kategori atau kelas dengan menggunakan rumus interval kelas. Interval kelas yang telah didapatkan yaitu sebesar 0,2 dan kategori skor keberlanjutan program One Village One Product (OVOP) melalui manajemen Koperasi Tani Mertanadi di Desa Pelaga, Kecamatan Petang, Kabupaten Badung dapat dirumuskan pada tabel 1 berikut ini.

\section{Tabel 1.}

Kategori Keberlanjutan Program One Village One Product melalui Manajemen Koperasi Tani Mertanadi di Desa Pelaga,

Kecamatan Petang, Kabupaten Badung

\begin{tabular}{ccc}
\hline Skor & Rentang Skor Interval Kelas & Kategori \\
\hline 1 & 1,00 sampai 1,80 & Sangat kurang berhasil \\
\hline 2 & $>1,80$ sampai 2,60 & Kurang berhasil \\
\hline 3 & $>2,60$ sampai 3,40 & Sedang \\
\hline 4 & $>3,40$ sampai 4,20 & Berhasil \\
\hline 5 & $>4,20$ sampai 5,00 & Sangat berhasil \\
\hline
\end{tabular}

\section{Hasil dan Pembahasan}

\subsection{Karakteristik Responden}

Responden penelitian berdasarkan karakteristik jenis kelamin, ditemukan bahwa jenis kelamin laki-laki berjumlah 67 orang dan sembilan orang adalah wanita. Karakteristik responden berdasarkan tingkat pendidikan formal paling tertinggi pada tingkat sekolah menengah atas (SMA) sebanyak 28 orang. Karakteristik sebagian besar 
responden berada pada rentang usia dua puluh satu sampai dengan enam puluh tahun dengan jumlah sebanyak tujuh puluh tiga orang, sedangkan tiga orang lainnya berusia di atas enam puluh tahun dengan status perkawinan sebanyak 74 orang sudah berstatus kawin dan dua orang yang berstatus belum kawin. Karakteristik responden menunjukkan luas lahan terbanyak yang dimiliki petani yaitu seluas kurang dari 0,5 hektar dengan jumlah petani sebanyak 57 orang dan nilai sebesar $75 \%$ dari total jumlah sampel petani.

\subsection{Keberlanjutan Program OVOP di Desa Pelaga}

Hasil penelitian menunjukkan bahwa keberlanjutan program OVOP melalui manajemen Koperasi Tani Mertanadi di Desa Pelaga, Kecamatan Petang, Kabupaten Badung dalam kategori berhasil dengan skor sebesar 4,00. Pencapaian skor setiap variabel meliputi, variabel perencanaan dengan skor sebesar 3,42 dengan kategori berhasil, variabel pengorganisasian dengan skor sebesar 3,90 dengan kategori berhasil, variabel pengarahan dengan skor sebesar 4,40 dengan kategori sangat berhasil, variabel pengendalian dengan skor sebesar 4,28 dengan kategori sangat berhasil. Secara lebih jelas masing-masing variabel disajikan pada tabel 2 berikut ini.

Tabel 2.

Tabulasi Skor Variabel Penelitian

\begin{tabular}{|c|c|c|c|}
\hline \multirow{2}{*}{ Variabel } & \multicolumn{2}{|c|}{ Pencapaian Skor } & \multirow{2}{*}{ Kategori } \\
\hline & Skor & $\%$ & \\
\hline Perencanaan & 3,42 & 68 & Berhasil \\
\hline Pengorganisasian & 3,90 & 78 & Berhasil \\
\hline Pengarahan & 4,40 & 88 & Sangat berhasil \\
\hline Pengendalian & 4,28 & 85 & Sangat berhasil \\
\hline
\end{tabular}

Berdasarkan tabel 2 di atas didapatkan bahwa variabel pengarahan memiliki nilai skor tertinggi yakni sebesar 4,40 dengan kategori sangat berhasil artinya kepemimpinan Koperasi Tani Mertanadi mampu menjalankan roda kepengurusan dengan sangat baik sehingga anggota Koperasi Tani Mertanadi puas dengan kinerja yang dijalankan oleh pengurus Koperasi Tani Mertanadi dan variabel perencanaan mendapatkan skor terendah yakni 3,42 dengan kategori berhasil. Penjabaran masing-masing variabel penelitian keberlanjutan program OVOP melalui manajemen Koperasi Tani Mertanadi di Desa Pelaga, Kecamatan Petang, Kabupaten Badung disajikan sebagai berikut.

\subsubsection{Perencanaan}

Perencanaan pengembangan program OVOP di tahun 2018, Koperasi Tani Mertanadi berfokus pada merealisasikan rencana program yang belum terlaksana dengan optimal di tahun sebelumnya. Pengembangan program OVOP pada tahun 2018, dalam hal menjaga keberlanjutan program diteliti dengan mengukur indikator dalam perumusan rencana kerja tahun 2018 di Koperasi Tani Mertanadi. Hasil penelitian 
keberlanjutan program OVOP melalui manajemen Koperasi Tani Mertanadi melalui indikator dari variabel perencanaan yaitu perumusan rencana kerja tahun 2018 diperoleh skor sebanyak 3,42. Kategori skor dalam perumusan rencana kerja tahun 2018 tergolong kategori berhasil. Variabel perencanaan memiliki 10 parameter yang digunakan untuk mengukur indikator perumusan rencana kerja tahun 2018 di Koperasi Tani Mertanadi, meliputi perumusan perencanaan program OVOP melibatkan anggota koperasi (P1), Koperasi Tani Mertanadi tetap dikelola oleh masyarakat asli Desa Pelaga (P2), pengembangan program OVOP memerlukan pembina yang ahli dalam budidaya asparagus (P3), pengembangan program OVOP tidak memerlukan dana hibah dari pemerintah (P4), pengembangan program OVOP tidak perlu menanam komoditi lain (P5), pengembangan program OVOP melakukan inovasi berupa membuat produk olahan dari asparagus (P6) melakukan ekspor terhadap komoditi asparagus (P7), tetap membagi sisa hasil usaha (SHU) terhadap anggota yang tidak aktif berproduksi (P8), melakukan pengembangan perluasan area penanaman asparagus (P9), dan menaikkan jumlah harga iuran simpanan pokok dan simpanan wajib untuk membantu biaya operasional (P10).

Parameter perumusan perencanaan program OVOP melibatkan anggota koperasi (P1) mendapatkan skor tertinggi, yaitu sebanyak 4,5 dengan kategori sangat berhasil. Proses perumusan perencanaan program yang melibatkan anggota menjadi unsur yang sangat penting dalam keberlanjutan program, karena anggota dapat memberikan masukan maupun kritikan pada perencanaan program. Parameter dengan skor terendah yaitu pengembangan program OVOP tidak perlu menanam komoditi lain (P5) mendapatkan skor sebanyak 1,81 dengan kategori kurang berhasil. Anggota tidak menyetujui apabila di tahun 2018 tidak membudidayakan komoditi selain asparagus, dikarenakan komoditi lain dapat menunjang pendapatan mereka walaupun hasil pendapatan yang diperoleh tidak sama seperti asparagus. Membudidayakan komoditi lain juga dapat memaksimalkan penggunaan lahan petani yang tidak dapat ditanami asparagus.

\subsubsection{Pengorganisasian}

Pengorganisasian dalam Koperasi Tani Mertanadi digunakan untuk membagi tugas dan tanggungjawab dalam memanajemen koperasi. Variabel pengorganisasian memiliki 10 parameter yang digunakan untuk mengukur indikator pengorganisasian di Lembaga Koperasi Tani Mertanadi, yaitu anggaran dasar sebagai pedoman dalam menjalankan Koperasi Tani Mertanadi (P11), struktur kepengurusan sebagai penunjuk kejelasan tanggungjawab pengelolaan Koperasi Tani Mertanadi (P12), proses pemilihan pengurus yang dilakukan dengan sistem demokrasi (P13), Koperasi Tani Mertanadi memerlukan pengawas dari luar keanggotaan koperasi (P14), DISKOPPERINDAG Kabupaten Badung sebagai tim pembina satu dalam pelaksanaan program OVOP (P15), Kepala Desa sebagai tim pembina dua pelaksanaan dalam program OVOP (P16), jangka waktu tiga tahun untuk melakukan pergantian pengurus (P17), merekrut anggota 
koperasi yang bukan berasal dari Desa Pelaga (P18), mengikutsertakan anggota Desa Belok Sidan sebagai pengurus di Koperasi Tani Mertanadi (P19), proses penyeleksian untuk menjadi anggota baru di Koperasi Tani Mertanadi (P20).

Hasil penelitian keberlanjutan program OVOP melalui manajemen Koperasi Tani Mertanadi melalui indikator dari variabel pengorganisasian yaitu perumusan pengorganisasian di Lembaga Koperasi Tani Mertanadi diperoleh skor sebanyak 3,90 dengan kategori skor berhasil. Parameter dengan skor terendah, yaitu Koperasi Tani Mertanadi memerlukan pengawas dari luar keanggotaan koperasi (P14) dengan perolehan skor sebanyak 1,64 dengan kategori sangat kurang berhasil. Pengawas dari dalam keanggotan dianggap sudah mampu dalam mengawasi jalannya Koperasi Tani Mertanadi sehingga tidak memerlukan pengawas dari luar keanggotaan koperasi. Parameter dengan skor tertinggi, yaitu mengikutsertakan anggota Desa Belok Sidan sebagai pengurus di Koperasi Tani Mertanadi (P19) mendapatkan skor sebanyak 4,56 dengan kategori sangat berhasil. Keterlibatan ini sudah diterapkan pada kepengurusan periode tahun 2014 s.d tahun 2017. Posisi sekretaris di jabat oleh I Dewa Made Medal yang berasal dari Banjar Kiadan, Desa Belok Sidan.

\subsubsection{Pengarahan}

Pengarahan dalam manajemen bersifat sangat kompleks karena pengarahan ini berfungsi untuk mengatur atau memberikan instruksi pada anggota dalam suatu organisasi. Pengarahan juga berfungsi untuk mengatur anggota dengan berbagai tingkah lakunya yang berbeda-beda dan memiliki pandangan serta pola hidup yang berbedabeda pula. Variabel pengarahan memiliki 10 parameter yang digunakan untuk mengukur indikator kepemimpinan yang dilakukan oleh pengurus Koperasi Tani Mertanadi, yaitu cara memimpin yang dilakukan oleh pihak pengurus Koperasi Tani Mertanadi (P21), peraturan di Koperasi Tani Mertanadi (P22), komitmen pengurus dalam mengelola Koperasi Tani Mertanadi (P23), petani mengikuti setiap arahan yang diberikan oleh pengurus (P24), penyelesaian permasalahan dengan cara kekeluargaan (P25), pengurus bersikap tidak memihak pada saat penyelesaian masalah (P26), pengurus bersikap terbuka terhadap setiap masukan yang diberikan oleh anggota (P27), kelancaran berkoordinasi petani dengan pengurus Koperasi Tani Mertanadi (P28), suasana kerja yang kondusif (tenang) di Koperasi Tani Mertanadi (P29), dan pemberian hadiah door prize sebagai pemacu semangat petani dalam berproduksi (P30).

Hasil penelitian keberlanjutan program OVOP melalui manajemen Koperasi Tani Mertanadi melalui indikator dari variabel pengarahan yaitu kepemimpinan yang dilakukan oleh pengurus Koperasi Tani Mertanadi diperoleh skor sebanyak 4,40 dengan kategori skor sangat berhasil. Parameter pemberian hadiah door prize sebagai pemacu semangat petani dalam berproduksi (P30) mendapatkan skor tertinggi, yaitu sebanyak 4,67 dengan kategori sangat berhasil. Pemberian hadiah door prize merupakan salah satu usaha pengurus Koperasi Tani Mertanadi untuk menjaga semangat anggota dan merangsang anggota untuk meningkatkan hasil produksinya. Peningkatan jumlah 
produksi memiliki pengaruh terhadap keberlanjutan program. Parameter petani mengikuti setiap arahan yang diberikan oleh pengurus (P24) mendapatkan skor terendah, yaitu sebanyak 4,05. Kepatuhan anggota mengikuti setiap arahan yang diberikan oleh pengurus mempengaruhi terhadap keberlanjutan program OVOP di Koperasi Tani Mertanadi, meskipun parameter ini tergolong rendah namun parameter ini tergolong kategori berhasil.

\subsubsection{Pengendalian}

Proses pengendalian di Koperasi Tani Mertanadi dilakukan dengan cara monitoring dan evaluasi. Monitoring dengan cara pengecekan langsung ke lapangan oleh pengurus yang dilakukan dengan frekuensi sebulan sekali. Evaluasi dilakukan dengan cara menilai data hasil monitoring yang didapatkan melalui interaksi petani dengan pengurus maupun berdasarkan pengecekan langsung di lapangan dan hasil evaluasi disampaikan pada saat rapat anggota tahunan (RAT).

Hasil penelitian keberlanjutan program OVOP pengendalian yaitu proses monitoring dan evaluasi Koperasi Tani Mertanadi tahun 2017 diperoleh skor sebanyak 4,28 dengan kategori skor sangat berhasil. Variabel pengendalian memiliki 10 parameter yang digunakan untuk mengukur indikator proses monitoring dan evaluasi di Koperasi Tani Mertanadi tahun 2017, yaitu pengawasan kondisi di lahan petani yang dilakukan setiap sebulan sekali oleh tim lapangan (P31), kelancaran pembayaran hasil penjualan sayur yang dilakukan setiap 15 hari sekali (P32), kehadiran anggota mengikuti Rapat Anggota Tahunan (RAT) di tahun 2017 (P33), pemberian bibit gratis oleh Koperasi Tani Mertanadi di tahun 2017 (P34), kelancaran Koperasi Tani Mertanadi dalam pemasaran produk asparagus di tahun 2017 (P35), realisasi pengembangan program OVOP tahun 2017 (P36), pemberian sanksi yang dilakukan oleh pengurus untuk anggota yang melakukan pelanggaran di tahun 2017 (P37), penanggulangan produk di luar grading (reject) oleh pengurus Koperasi Tani Mertanadi tahun 2017 (P38), transparansi pembagian Sisa Hasil Usaha (SHU) yang dilakukan oleh koperasi tani Mertandi pada tahun 2017 (P39), dan kinerja pengurus dalam manajemen Koperasi Tani Mertanadi pada tahun 2017 (P40).

Parameter transparansi pembagian Sisa Hasil Usaha (SHU) yang dilakukan oleh koperasi tani Mertandi pada tahun 2017 (P39), mendapatkan skor tertinggi, yaitu sebanyak 4,56 dengan kategori sangat berhasil. Transparansi pembagian sisa hasil usaha ini tentunya akan sangat mempengaruhi keanggotaan serta keberlanjutan program OVOP ini. Anggota koperasi baru mendapatkan pembagian sisa hasil usaha (SHU) di kepengurusan periode 2014 s.d 2017 ini, pada kepengurusan sebelumnya anggota tidak pernah mendapatkan sisa hasil usaha (SHU) dikarenakan transparansi yang tidak baik di kepengurusan sebelumnya. Parameter dengan skor terendah yaitu pada parameter pengawasan kondisi di lahan petani yang dilakukan setiap sebulan sekali oleh tim lapangan (P31) dengan skor skor sebanyak 3,76 dalam kategori berhasil. Tim lapangan ini baru terbentuk pada tahun 2017, pembentukan tim lapangan ini bertujuan selain 
mengawasi kondisi lahan petani, juga mengawasi petani yang hendak ingin menjual produk asparagus mereka ke luar dari koperasi. Kinerja tim ini termasuk dalam kategori berhasil meskipun tim ini baru dibentuk dan anggota tim ini berjumlah satu orang.

\section{Kesimpulan dan Saran}

\subsection{Kesimpulan}

Keberlanjutan program OVOP melalui Koperasi Tani Mertanadi ini ditinjau berdasarkan fungsi-fungsi manajemen. Fungsi-fungsi manajemen, meliputi perencanaan, pengorganisasian, pengarahan, dan pengendalian. Fungsi-fungsi manajemen ini dijadikan sebagai variabel dalam penelitian ini. Berdasarkan hasil penelitian, keberlanjutan program OVOP Koperasi Tani Mertanadi ditinjau dari fungsifungsi manajemen yang telah terlaksana dikategorikan berhasil. Variabel pengarahan melalui indikator kepemimpinan yang dilakukan oleh pengurus Koperasi Tani Mertanadi memiliki nilai skor tertinggi diantara keempat variabel lainnya dengan perolehan skor sebesar 4,40 dengan kategori sangat berhasil artinya kepemimpinan Koperasi Tani Mertanadi mampu menjalankan roda kepengurusan dengan sangat baik sehingga anggota Koperasi Tani Mertanadi puas dengan kinerja yang dijalankan oleh pengurus Koperasi Tani Mertanadi.

Kendala atau permasalahan dalam manajemen Koperasi Tani Mertanadi dibagi menjadi tiga aspek, yaitu aspek teknis, aspek ekonomi, dan aspek sosial. Berdasarkan hasil wawancara dengan pengurus Koperasi Tani Mertanadi Bapak I Wayan Supariyasa kendala aspek teknis meliputi kendala dalam melakukan budidaya dari segi hama dan penyakit, dari segi kerugian akibat adanya produk reject. Aspek ekonomi meliputi permasalahan produk reject dan produk yang tidak dapat dipasarkan. Aspek sosial meliputi permasalahan kecurangan anggota yang sengaja menjual produk ketika harga naik ke tengkulak namun pada saat harga rendah jual ke koperasi menimbulkan adanya konflik sosial dikalangan anggota koperasi yang menjual produknya hanya di koperasi.

\subsection{Saran}

Meski keberlanjutan program OVOP melalui manajemen Koperasi Tani Mertanadi ini mendapatkan sudah berhasil dijalankan, koperasi diharapkan dapat mengatasi permasalahan yang ada di dalam koperasi dimana permasalahan meliputi kendala dalam aspek teknis, aspek sosial dan aspek ekonomi. Saran yang dapat diberikan oleh peneliti yakni pertama pengurus Koperasi Tani Mertanadi perlu menegaskan kembali mengenai anggota yang tidak aktif berproduksi masih dinyatakan bergabung atau dikeluarkan dari keanggotaan koperasi. Kedua Koperasi Tani Mertanadi diharapkan dapat segera melaksanakan program pelatihan pengolahan pasca panen asparagus. Pengolahan produk mentah asparagus menjadi produk olahan baru seperti kripik asparagus atau jenis makanan lainnya. Produk olahan ini diharapkan dapat menjadi solusi untuk menanggulangi hasil produk asparagus reject yang tidak dapat di jual menjadi produk baru yang bernilai lebih tinggi. 


\section{Ucapan Terima Kasih}

Ucapan terimakasih penulis tujukan kepada Koperasi Tani Mertanadi serta semua pihak yang telah membantu pelaksanaan pelaksanaan penelitian hingga karya ilmiah ini dapat dipublikasikan secara e-jurnal

\section{Daftar Pustaka}

Agustini, Yanti. 2013. Tulisan tentang OVOP. Binausaha Koperasi dan UKM. Badung. Amirullah dan Haris Budiono. 2004. Pengantar Manajemen: Cetakan Kedua. Graha Ilmu. Yogyakarta.

Bungin, Burhan. 2003. Analisis Data Penelitian Kualitatif: Pemahaman Filosofis dan Metodologis ke Arah Penguasaan Model Aplikasi. Rajagrafindo Persada.Jakarta.

Ghozali, Imam. 2011. Aplikasi Analisis Multivariate dengan Program SPSS. Badan Penerbit Universitas Diponegoro. Semarang.

Gunawan, Imam. 2015. Metode Penelitian Kualittif. Internet. http://fip.um.ac.id/wpcontent/uploads/2015/12/3_Metpen-Kualitatif.pdf. (diakses pada tanggal 01 Oktober 2017).

Indah Pratiwi, Rianita. 2016. Evaluasi Pelaksanaan Program One Village One Product (Ovop) dalam Pemberdayaan Masyarakat di Desa Pelaga, Kecamatan Petang, Kabupaten Badung. Skripsi. Program Studi Administrasi Negara. Fakultas Ilmu Sosial Dan Ilmu Politik. Universitas Udayana.

Rahayu, Nita. 2015. Aspek Kelayakan Finansial Pengembangan Komoditas Asparagus (Asparagus offcionalis) di Desa Pelaga, Kecamatan Petang, Kabupaten Badung. Skripsi. Program Studi Agribinis. Fakultas Pertanian. Universitas Udayana.

Robbins, Stephen P. dan Mary Coulter. 2010. Manajemen. Erlangga. Jakarta.

Sudomoningrat, Gunawan dan Wulandari. 2015. Menuju Ekonomi Berdikari: Pemberdayaan UMKM dengan Konsep OPOP, OVOP, OVOC. Media Pressindo. Yogyakarta.

Sudomoningrat, Gunawan dan Wulandari. 2016. Membangun Indonesia dari Desa: Pemberdayaan Desa sebagai Kunci Kesuksesan Pembangunan Ekonomi untuk Meningkatkan Kesejahteraan Rakyat. Media Pressindo. Yogyakarta. 